\title{
ADVANTAGES AND WEAKNESSES OF PERCUTANEOUS ENDOSCOPIC LUMBAR DISCECTOMY: ALGORITHM SELECTION
}

\author{
VANTAGENS E FRAQUEZAS DA DISCECTOMIA LOMBAR ENDOSCÓPICA PERCUTÂNEA: \\ SELEÇÕES DE ALGORITMO
}

\author{
VENTAJAS Y DEBILIDADES DE LA DISCECTOMÍA LUMBAR ENDOSCÓPICA PERCUTÁNEA: \\ SELECCIÓN DE ALGORITMO
}

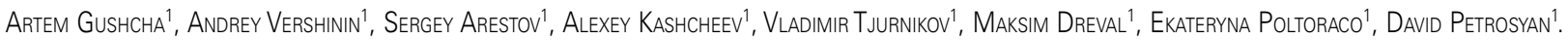

1. Neurology Research Center of the Russian Academy of Sciences, Department of Neurosurgery, Volokolamskoe Avenue, Moscow, Russia.

\begin{abstract}
Objective: Degenerative diseases of the spine are the most common disorder seen in the practice of the neurosurgeon. According to many surgeons, microdiscectomy is the "gold standard" of surgical treatment. Analyzing the current literature, it is seen that the use of endoscopic techniques in spinal surgery is increasing. However, due to the lack of detailed information on the advantages and disadvantages of these methods, there is a need for continuing research in this area. Work to clarify the features of these methods, their specificity and algorithmization will increase the effectiveness of surgical treatment. Methods: This study included patients with herniated lumbar intervertebral discs, the presence of pain in the leg, and failed of conservative therapy. In the period 2014 to 2017, 172 endoscopic lumbar discectomies were performed, using microendoscopic discectomy and percutaneous endoscopic lumbar discectomy. The effectiveness of each technique was evaluated through comparative analysis. Results: In both groups, the methods used obtained high efficacy rates. Comparative analysis showed the advantages of the percutaneous technique in terms of shortening the return to normal activity time, hospitalization time, and disability, and reducing back pain in the early postoperative period. On the other hand, the microendoscopic discectomy enabled greater radicality to be achieved in cases with herniated disc ossification and complex anatomy of the vertebral segment. Conclusions: Analysis of the data obtained led to the formulation of an algorithm for selecting the optimum endoscopic method for achieving positive results of surgical treatment. Level of Evidence II; Therapeutic studies, investigating the results of treatment.
\end{abstract}

Keywords: Intervertebral disc displacement; Diskectomy; Neuroendoscopy.

\section{RESUMO}

Objetivo: As doenças degenerativas da coluna vertebral estão em primeiro lugar, de acordo com a frequência de ocorrência na prática de um neurocirurgião. De acordo com muitos cirurgiões, a microdiscectomia é o "padrão-ouro" do tratamento cirúrgico. Ao analisar as publicações atuais, há uma tendência em aumentar o uso de técnicas endoscópicas na cirurgia da coluna vertebral. A falta de informações detalhadas sobre as vantagens e desvantagens desses métodos leva à necessidade de continuar a pesquisa nessa direção. Realizar o trabalho detalhando as características desses métodos, sua especificidade e algoritmo aumentará a eficácia do tratamento cirúrgico. Métodos: O estudo incluiu pacientes com discos intervertebrais lombares com hérnia, presença de dor na perna e a não eficácia da terapia conservadora. No período de 2014 a 2017, 172 discectomias lombares endoscópicas foram realizadas. O estudo utilizou discectomia microendoscópica e discectomia lombar endoscópica percutânea. Sua eficácia e análise comparativa foram avaliadas. Resultados: Em ambos os grupos, foram obtidas altas taxas de eficácia dos métodos utilizados. A análise comparativa mostrou as vantagens dos métodos percutâneos sob a forma de encurtamento dos períodos de ativação, hospitalização, incapacidade e redução da dor nas costas no pós-operatório precoce. A discectomia microendoscópica permite alcançar maior radicalidade em casos de ossificação do disco herniado e anatomia complexa do segmento vertebral. Conclusões: A análise dos dados obtidos possibilitou a formulação de um algoritmo para seleção do método endoscópico, que permite alcançar resultados positivos no tratamento cirúrgico. Nível de Evidência II; Estudos terapêuticos, investigando os resultados do tratamento.

Descritores: Des/ocamento do disco intervertebral; Discotomia; Neuroendoscopia.

\section{RESUMEN}

Objetivo: Las enfermedades degenerativas de la columna vertebral son el trastorno más común visto en la práctica de un neurocirujano. Según muchos cirujanos, la microdiscectomía es el "estándar de oro" del tratamiento quirúrgico. Al analizar publicaciones actuales, se puede notar que el uso de técnicas endoscópicas en la cirugía espinal está aumentando. Sin embargo, la falta de información detallada sobre las ventajas y desventajas de estos métodos lleva a la necesidad de continuar investigando en esta dirección. Llevar a cabo un trabajo para detallar las características de estos métodos, su especificidad y algoritmización aumentará la efectividad del tratamiento quirúrgico. Métodos: Este estudio incluyó a pacientes con discos intervertebrales lumbares herniados, la presencia de dolor en la pierna y falla de la terapia conservadora. En el período de 2014 a 2017, se realizaron 172 discectomías lumbares endoscópicas, utilizando discectomía microendoscópica y discectomía lumbar endoscópica percutánea. La efectividad de cada técnica fue evaluada a través de análisis comparativo. 
Resultados: En ambos grupos, se obtuvieron altas tasas de eficacia de los métodos utilizados. El análisis comparativo mostró las ventajas del método percutáneo cuanto al acortamiento de los períodos para retorno a las actividades, tiempo de hospitalización y discapacidad y reducción del dolor de espalda en el período postoperatorio temprano. Por otro lado, la discectomía microendoscópica permite lograr una mayor radicalidad en casos con osificación de disco herniado y anatomía compleja del segmento vertebral. Conclusiones: El análisis de los datos obtenidos permitió formular un algoritmo para seleccionar el mejor método endoscópico para obtener resultados positivos del tratamiento quirúrgico. Nivel de Evidencia II; Estudios terapéuticos que investigan los resultados del tratamiento.

Descriptores: Desplazamiento del disco intervertebral; Discectomía; Neuroendoscopía.

\section{INTRODUCTION}

One of the most common reasons for going to the doctor is back pain. $80-100 \%$ of the world's population have suffered this kind of pain at some time in their lives. In any given year, around $20 \%$ of the population and $50 \%$ of the working-age population will suffer from back pain. ${ }^{1-3}$ Back pain, particularly of vertebrogenic cause, significantly limits patients' activity, affecting quality of life and in some cases, causing psychological and emotional changes. ${ }^{4}$ The increasing lifespan of the able-bodied population, a lack of regular exercise, and poor nutrition have led to excessive body weight, dysfunction of the deep muscle corset system, and age-related degenerative-dystrophic changes in the spine. As a result, the number of cases of herniated intervertebral discs has increased. Degenerative and dystrophic diseases of the spine are the most frequent occurrence in the practice of the neurosurgeon. In the presence of a herniated intervertebral disc, failure of conservative therapy and/or an increase in neurological deficit, surgical treatment is indicated. Most operations associated with intervertebral disc herniation performed at the lumbar level are performed using a microscope and can be combined under the term "microdiscectomy". According to many surgeons, this is the "gold standard" of surgical treatment. However, the desire to reduce the amount of intervention, blood loss, and risks of possible delayed complications have led to the active introduction of endoscopic technologies aimed primarily at improving the patient's quality of life and reducing invasiveness compared with traditional open operations.

Analyzing the current literature, it is seen that the use of endoscopic techniques in spinal surgery is increasing. Percutaneous endoscopic methods of treating herniated intervertebral disc enables good results to be achieved in patients with pain in the leg. Due to a lack of detailed information on the advantages and disadvantages of these methods, there is a need for continuing research in this area. Work to clarify the features of these methods, their specificity and algorithmization will increase the effectiveness of surgical treatment. Thus, the purpose of this study is to determine the advantages and disadvantages of percutaneous endoscopic lumbar discectomy, and formulate an algorithm for choosing the best surgical technique.

\section{METHODS}

\section{General data on the study group}

The study included patients with herniated lumbar intervertebral discs, the presence of pain in the leg, and failure of conservative therapy. In the period 2014 to 2017, 172 endoscopic lumbar discectomies were performed, which were divided into two groups: 1. The main group consisted of 86 patients who underwent percutaneous endoscopic lumbar discectomies (PELD) (of which 38 (44\%) were men). The "Inside out" (Spine TIP, Karl Storz, Germany) and "Outside in" (TESSYS, Joymax, Germany) methods were used. 2. A control group of 86 patients (of which 35 (41\%) were men) who underwent microendoscopic discectomy (MED) using tubular retractors and video guidance (Easy Go, Karl Storz, Germany).

Exclusion criteria were: patients under 18 or over 80 years of age, patients with no pain in the leg, patients with scoliotic deformities, spondylolisthesis, or instability at the level of the proposed surgical intervention, and patients with absolute contraindications to routine surgical treatment.

The study was approved by the local ethics review board of the FGBNU NSC (protocol No. 10/13 of 16/10/13). Informed consent was signed by all patients. Intergroup comparison in the pre-operative period showed the statistical comparability of the two groups (Table 1).

\section{Description of surgical methods}

PELD a surgical treatment method for herniated intervertebral discs, full endoscopic surgery, performing a skin incision of up to $1 \mathrm{~cm}$ and puncture access through the surrounding tissues. A special feature of this technique is that it causes minimal trauma, due to the delicacy of the operation and the surgical instruments used. Three access variants (intralaminar, posterolateral and transforaminal) were used, and two variants in the method of performing the access - posterolateral or transforaminal ("Inside out" and "Outside in"). In the intralaminar access, the surgery is performed through the interstitial space, passing through the vertebral canal and displacing the root (Figure 1)

In the percutaneous posterolateral and transforaminal access, a working cannula is introduced into the foramen, with decompression and visualization of the root. The "Inside out" option involves the insertion of a cannula into the intervertebral disc, removal of the hernia and visualization of the achieved decompression of the nerve root, which is in the direction of the foramen exit (Figure 2)

The "Outside in" option involves primary decompression with the formation of a resection of the articular process in the medial

Table 1. The general table of statistical reliability of comparability of the two groups (Mann-Whitney test)

\begin{tabular}{|c|c|c|c|c|}
\hline $\mathbf{N}$ & Criterion & $\begin{array}{c}\text { PELD } \\
\text { (Me[LQ;UQ]) }\end{array}$ & $\begin{array}{c}\text { MED } \\
\text { (Me[LQ;UQ]) }\end{array}$ & p-value \\
\hline 1 & Floor & \multicolumn{3}{|c|}{0.54 (Fisher's test) } \\
\hline 2 & Age, years & $41.5[32 ; 48]$ & $44.5[40 ; 55]$ & 0.062883 \\
\hline 3 & $\begin{array}{c}\text { Anamnesis of back pain, } \\
\text { months }\end{array}$ & $36[26 ; 36]$ & $24[24 ; 36]$ & 0.944505 \\
\hline 4 & $\begin{array}{c}\text { Anamnesis of leg pain, } \\
\text { months }\end{array}$ & $2[1 ; 4]$ & $4[1 ; 5]$ & 0.343464 \\
\hline 5 & $\begin{array}{c}\text { Time of observation, } \\
\text { months }\end{array}$ & $19.5[16 ; 25]$ & $18.5[13 ; 23]$ & 0.194165 \\
\hline 6 & $\begin{array}{l}\text { VAS of back pain before } \\
\text { surgery, points }\end{array}$ & $5[4 ; 5]$ & $5[4 ; 5]$ & 0.932568 \\
\hline 7 & $\begin{array}{l}\text { VAS of leg pain before } \\
\text { surgery, points }\end{array}$ & $6[6 ; 7]$ & $6[6 ; 7]$ & 0.515710 \\
\hline 8 & $\begin{array}{c}\text { Sensitivity disorders before } \\
\text { surgery, scores }\end{array}$ & $4[3 ; 5]$ & $4[3 ; 5]$ & 0.896248 \\
\hline 9 & $\begin{array}{l}\text { Movement disorders } \\
\text { before surgery, scores }\end{array}$ & $5[5 ; 5]$ & $5[5 ; 5]$ & 0.675132 \\
\hline 10 & ODI before surgery, scores & $66[58 ; 78]$ & $68[62 ; 78]$ & 0.834356 \\
\hline
\end{tabular}

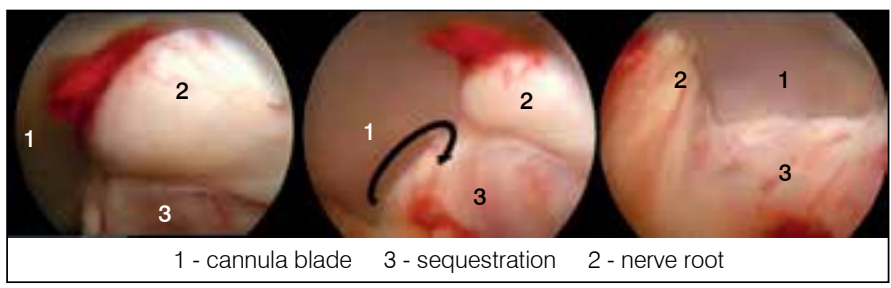

Figure 1. Stages of intralaminar access, from left to right: visualization, rotation and displacement of the root, safe position of the scapula for the removal of the hernia. 


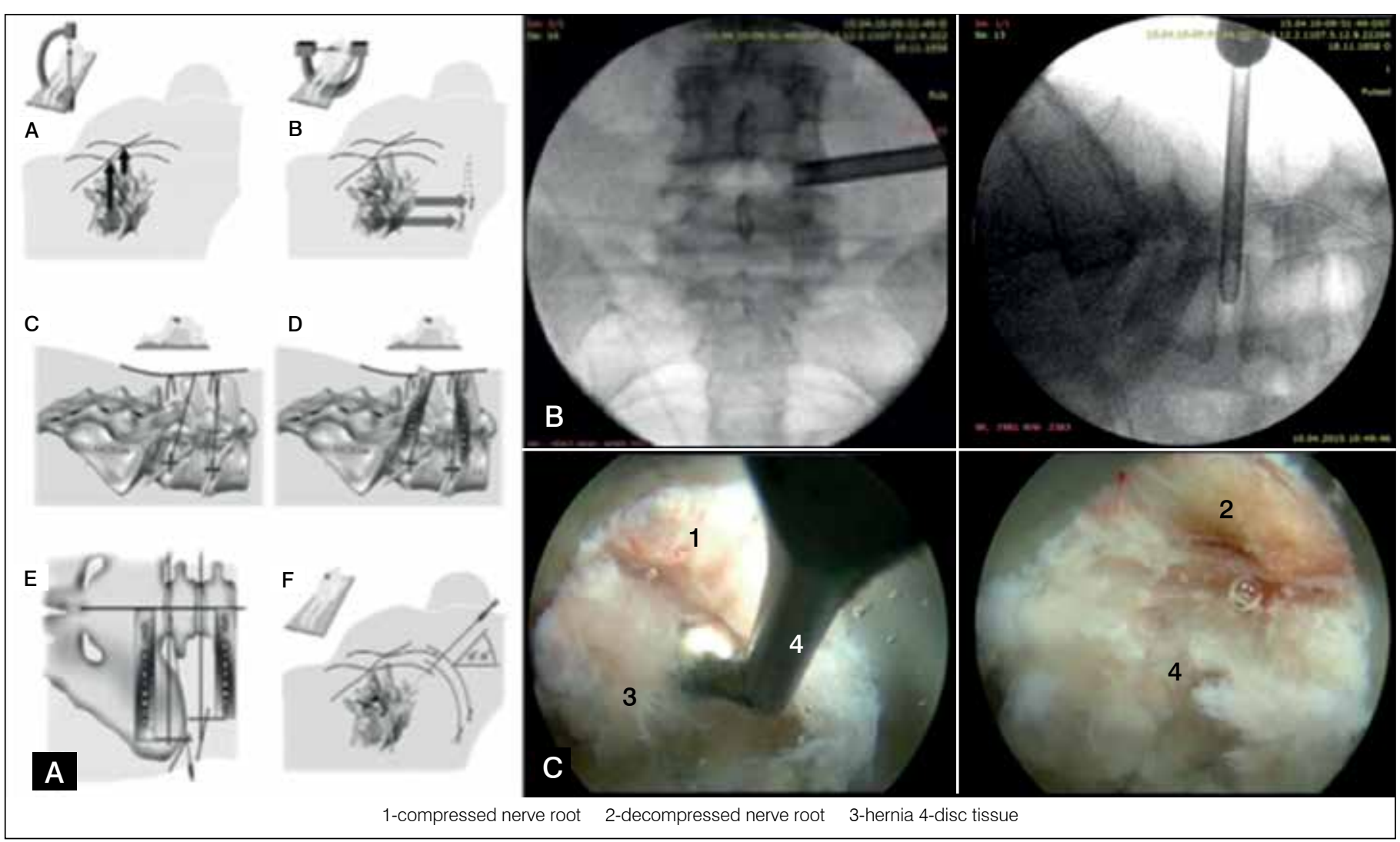

Figure 2. PELD "Inside out" method. A - A. Young access system; ${ }^{5}$ B- X-ray correct position of cannula C-stages of decompression.

direction to the area of compression of the nerve root and without entry into the intervertebral disc (Figure 3).

Microendoscopic discectomy (MED) is a method based on microsurgical removal techniques, using tubular retractors and endoscopic imaging. This method uses standard microsurgical instruments, but manipulation is carried out through a working port with a diameter of $14-18 \mathrm{~mm}$ created in the paravertebral muscles. For the microendoscopic discectomy, interlaminar and posterolateral approaches were used (Figure 4).

\section{Criteria and methods of evaluation}

The patients of both groups were examined four times (before surgery, on day 1 , and 6 and 12 months after the operation). To determine the effectiveness of the methods and compare them, the mean indices of activation, hospitalization, temporary incapacity for work and the frequency of complications in the two groups were calculated and compared.

All patients signed an informed consent form and read the information sheet. This was followed by collection of complaints and anamnesis, detailed clinical and neurological examination, MRI (on a Siemens Magnetom Avanto 1.5 T. (Germany) in T1 and T2 modes, STIR) and CT scan of the lumbar department (on a "SOMATOM Definition AS 40" "Siemens" apparatus (Germany) in bone and soft tissue modes), to determine the degree of ossification of the hernia and the presence of marginal osteophytes, functional spondylography (in the lateral projection, to detect instability) on the Visual Analog Scale, Oswestry Disability Index, and Macnab Scale.

Statistical processing of the data was carried out using the software "STATISTICA 8.0" (StatSoft, USA). For the quantitative parameters, the frequency and proportion (as a \%) of the total number of patients in each group were calculated. To compare the frequencies of a binary feature in two independent groups, an analysis of the 2x2 tables was performed, performing Fisher's exact test for small samples. For the quantitative parameters, the Median, 25th and 75th percentile, mean and the standard deviation from the mean were calculated. For the non-normal distribution of characteristics, the data were presented as median and interquartile interval Medians [LQ; UQ]. The reliability evaluation was carried out using a nonparametric Mann-Whitney test to compare two unrelated groups. For the normal distribution of characteristics, criteria of parametric comparison were used. $p<0.05$ was considered indicative of statistical significant difference.

\section{RESULTS}

In the main group, the activation time was 10 [9;12] hours, and in the control group, it was $14[13 ; 16]$ hours. Thus, the patients of the main group became active earlier, which indicates less surgical trauma for the PELD (Mann-Whitney U Test, p <0.001) (Figure 5).

In the study of hospitalization times, there was a significant decrease in the number of patients in the PELD group, with median values of $2[2 ; 3]$ days compared to the MED group, with median values of $4[3 ; 4]$ hours (Mann-Whitney $\cup$ Test, $p<0.001$ ) (Figure 6).

Estimating the time of temporary incapacity for work from the moment of patient discharge from the hospital, a significant decrease in the PELD group was revealed (Mann-Whitney $U$ Test, $p$ $<0.001)$. The median value for time of incapacity for work in the PELD group was $2[2 ; 3]$ weeks, and in the MED group, it was $3[3 ; 4]$ weeks. Thus, it was deduced that the patients of the PELD group had shorter recovery times and earlier return to work.

In the first day after the operation, the level of back pain in the PELD group was -1 [1;2] points, which was significantly less than in the MED group, with -3 [2;3] points. Leg pain in the PELD group was $-1[0 ; 1]$, and in the MED group, $0[0 ; 0]$ by the VAS (Mann-Whitney $U$ Test, $p<0.001$ ). Six months later, the level of back pain in the patients of the PELD group was $-0[0 ; 1]$, and in the MED group, -1 $[1 ; 2]$ (Mann-Whitney $\cup$ Test, $p<0.001$ ), and leg pain, both in the PELD group, and in the MED level of the pain syndrome according to the VAS was 0 [0;0] Thus, a significant advantage of PELD was revealed in the early and late postoperative periods (Figure 7 ).

Assessing the quality of life according to the Oswestry Disability Index, a significant improvement in the quality of life was observed in the patients of both groups. In the intergroup comparison, the indices did 


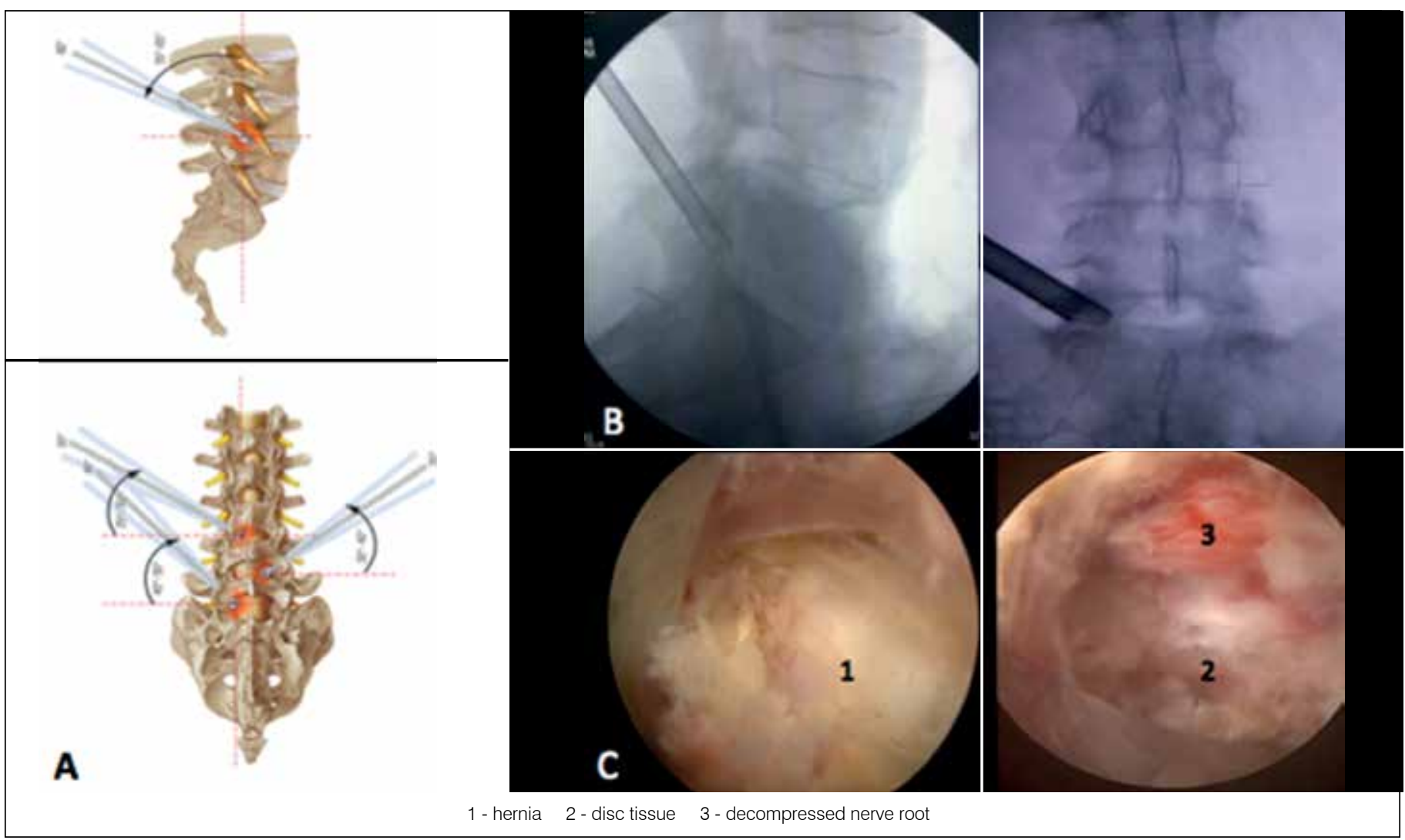

Figure 3. PELD "Outside in" method. A - T. Hoogland access system; ${ }^{6}$ B- X-ray correct position of cannula C-stages of decompression.
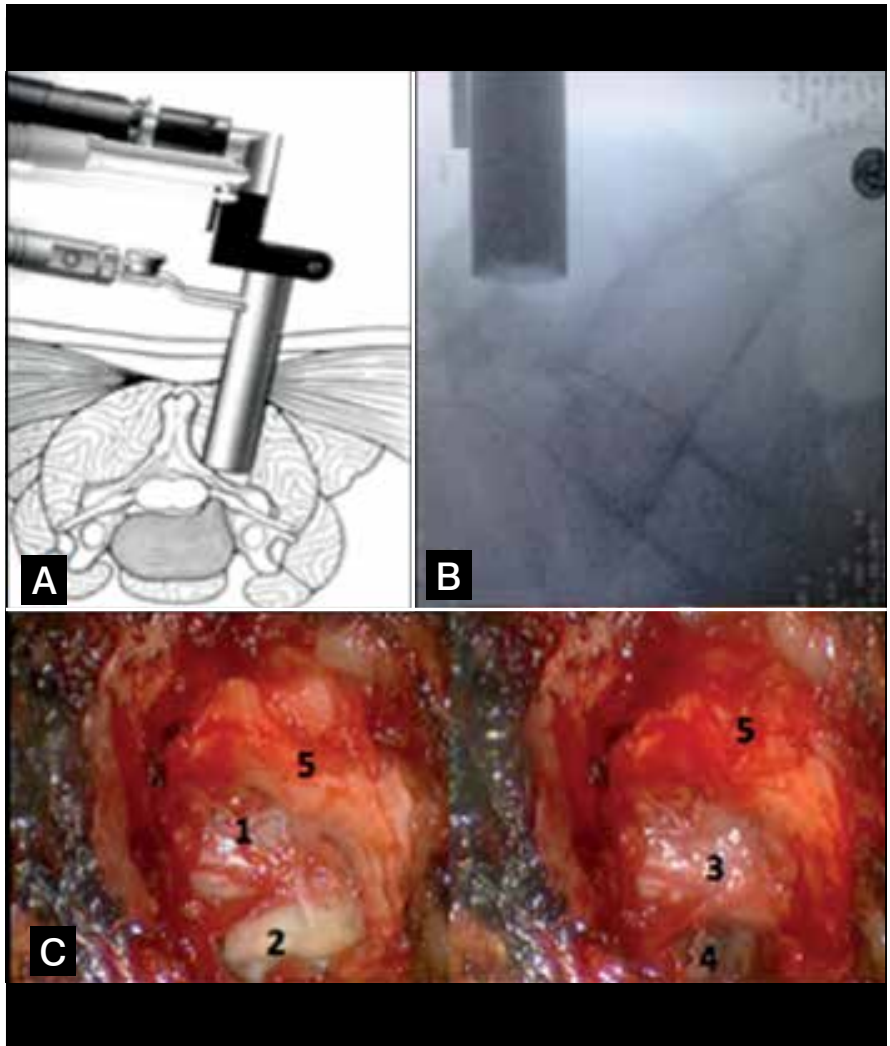

1 - compressed nerve root, 2 - hernia 3 - decompressed nerve root 4 - disc tissue; 5 - yellow ligament

Figure 4. Microendoscopic discectomy A - Access system; ${ }^{6}$ B- X-ray correct position tubular retractor; C-stages of decompression.

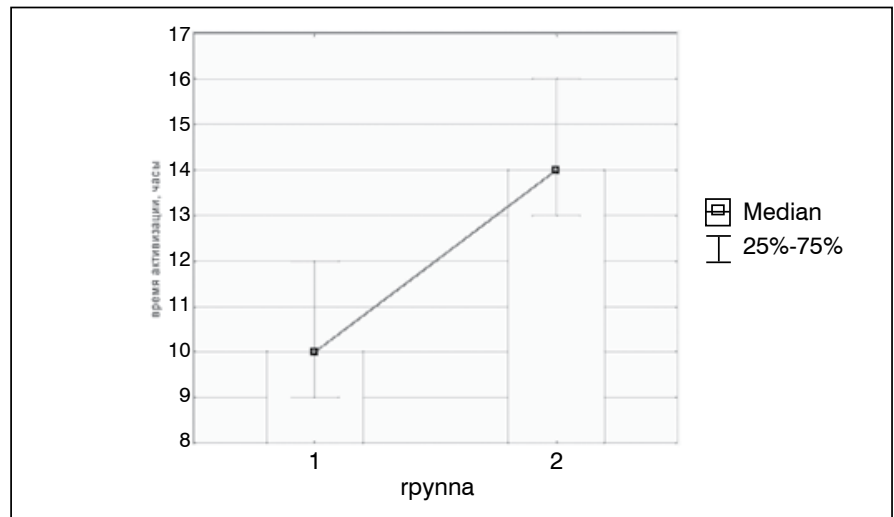

Figure 5. Activation time in two groups.

not differ significantly after 6 months (Mann-Whitney $\cup$ Test, $p=0.299$ ), or after 12 months (Mann-Whitney $\cup$ Test, $p=0.133$ ) (Figure 8).

Assessing the surgical treatment performed, according to Macnab's subjective evaluation scale, there was a persistent prevalence of excellent and good results throughout the entire 12-month postoperative follow-up. The statistical processing of the data showed no significant differences (Mann-Whitney $\cup$ Test, $p=0.324$ on day 1 , $p=0.766$ after 6 months and $p=0.57$ after 12 months) (Table 2).

During the course of the study, an analysis of surgical complications was carried out, and the means used to minimizing them were determined. In the two groups $(n=172)$, there were 13 clinical cases in which complications of surgical intervention were recorded, i.e. $7.6 \%$. Intergroup analysis showed that the incidence of surgical complications in the PELD group was $n=8,9.3 \%$, and in the MED group $n=5,5.8 \%$. Accordingly, the incidence of complications in the PELD group was somewhat higher (Table 3).

Based on the results of this study, an algorithm was developed to select the best endoscopic method for surgical treatment of herniated intervertebral discs of the lumbosacral spine (Figure 9). 


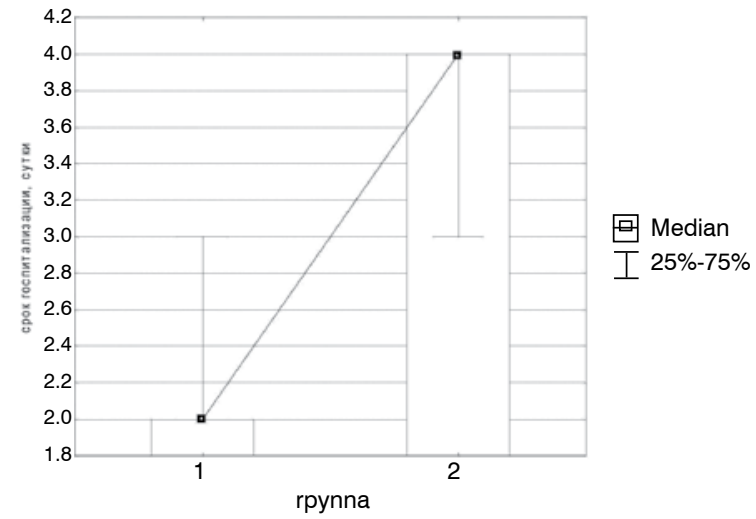

Figure 6. Time of hospitalization in two groups.

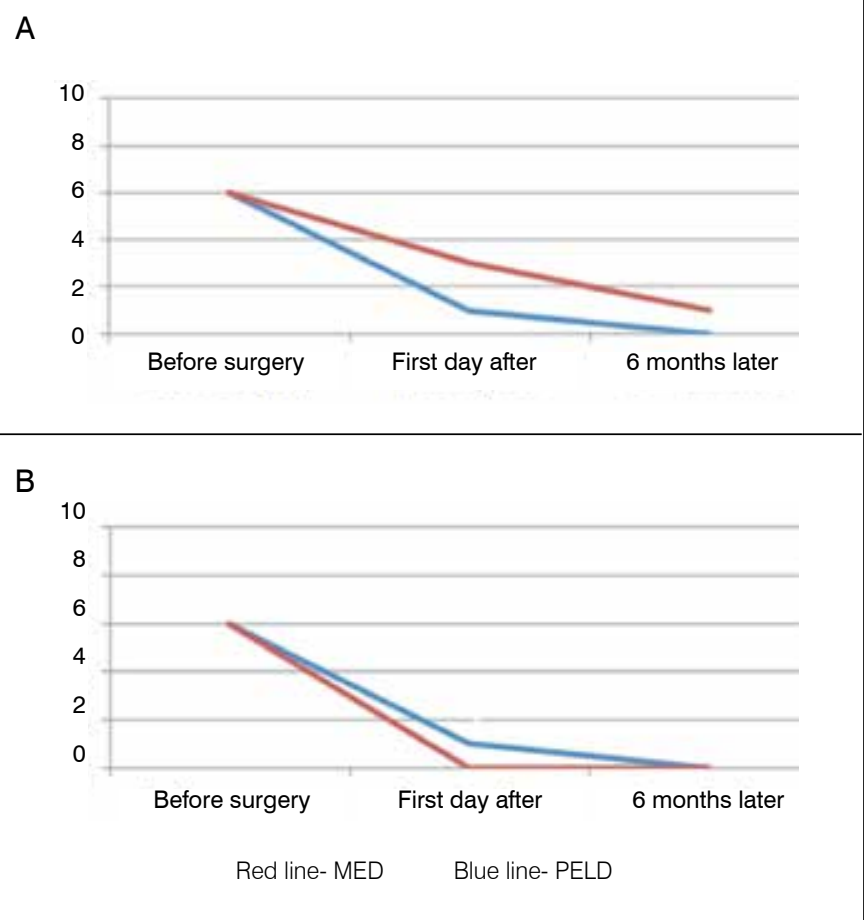

Figure 7. A- dynamics of back pain in VAS; B- dynamics of leg pain in VAS.

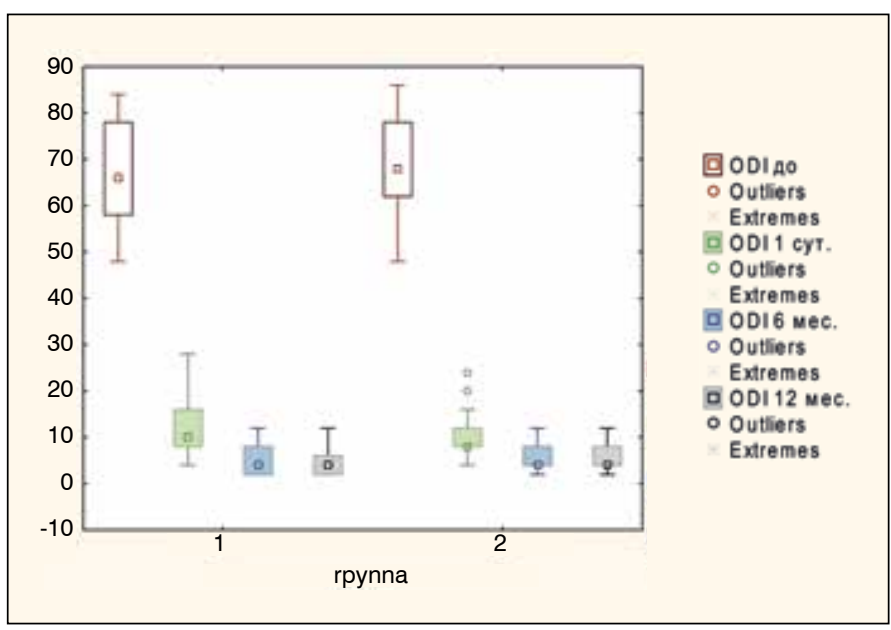

Figure 8. Dynamics of the quality of life by Oswestry Disability Index.
Table 2. Results of surgical treatment on the Macnab scale.

\begin{tabular}{|c|c|c|c|c|c|c|c|}
\hline \multirow{3}{*}{ Group } & \multirow{3}{*}{ Result/points } & \multicolumn{6}{|c|}{ After surgery } \\
\hline & & \multicolumn{2}{|c|}{1 day } & \multicolumn{2}{|c|}{6 months } & \multicolumn{2}{|c|}{12 months } \\
\hline & & $\mathbf{N}$ & $\%$ & $\mathbf{N}$ & $\%$ & $\mathbf{N}$ & $\%$ \\
\hline \multirow{3}{*}{ PELD } & Excellent/4 & 63 & $73.5 \%$ & 68 & $79.4 \%$ & 73 & $85.3 \%$ \\
\hline & Good/3 & 20 & $23.5 \%$ & 18 & $20.6 \%$ & 13 & $14.7 \%$ \\
\hline & Satisfactorily/2 & 3 & $3 \%$ & 0 & $0 \%$ & 0 & $0 \%$ \\
\hline \multirow{3}{*}{ MED } & Excellent/4 & 53 & $61.8 \%$ & 71 & $82.3 \%$ & 68 & $79.4 \%$ \\
\hline & Good/3 & 30 & $35.2 \%$ & 15 & $17.7 \%$ & 18 & $20.6 \%$ \\
\hline & Satisfactorily/2 & 3 & $3 \%$ & 0 & $0 \%$ & 0 & $0 \%$ \\
\hline
\end{tabular}

Table 3. Surgical complications.

\begin{tabular}{c|c|c|c|c}
\hline \multirow{2}{*}{ Group } & \multicolumn{4}{|c}{ Variants of complications, (n) } \\
\cline { 2 - 5 } & Relapse & Bleeding & $\begin{array}{c}\text { Postoperative } \\
\text { neuritis }\end{array}$ & $\begin{array}{c}\text { Increased neurological } \\
\text { deficit }\end{array}$ \\
\hline PELD & 2 & 0 & 4 & 2 \\
\hline MED & 2 & 2 & 1 & 0 \\
\hline
\end{tabular}

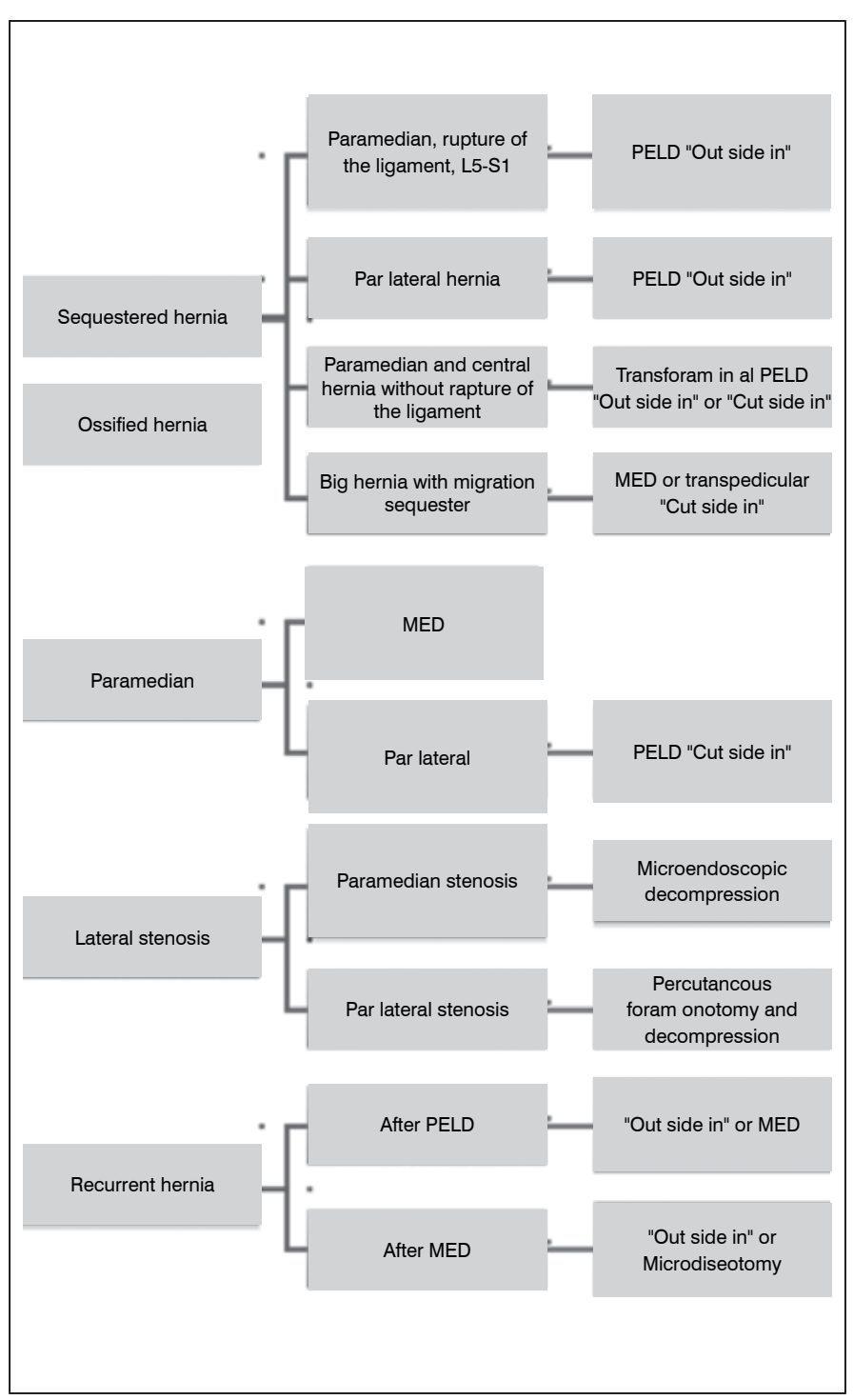

Figure 9. The algorithm for selecting the best endoscopic method for surgical treatment. 


\section{DISCUSSION}

The statistical analysis of the results of surgical treatment of patients with herniated intervertebral discs of the lumbosacral spine resulted in the indication of the percutaneous endoscopic method. The advantages of this method are described in detail, and include greater radicality with minimal trauma. The algorithm developed for selecting the optimal endoscopic method enables greater efficiency of the surgery and shorter recovery times for patients. Thus, the proposed goal of this work was achieved and the research tasks were solved.

\section{CONCLUSIONS}

1. The advantage of percutaneous endoscopic lumbar discectomy is a significant reduction in return to normal activity times, hospitalization for temporary disability, and level of back pain in the early postoperative period. These aspects lead to shorter rehabilitation times for patients.

2. Disadvantages of percutaneous endoscopic lumbar discectomy are a lack of sufficient radicality due to ossification of the hernia and/or complicated anatomy of the intervertebral foramen in clinical cases.

3. The developed algorithm divides herniated intervertebral discs by anatomical localization, size, and the presence of osteophytes, and determines the optimal tactics of surgical treatment by endoscopic methods.

All authors declare no potential conflict of interest related to this article.

CONTRIBUTION OF THE AUTHORS: Each author contributed individually and significantly to the development of the manuscript. AG (0000-0003$3451-5750)^{\star}$, AV (0000-0002-8006-1334)* and SA (0000-0003-4809-4117)* were the main contributors in the drafting of the manuscript. AK (0000-00017681-3073)* and MD (0000-0002-7839-309X)* performed the surgery, followed up the patients and gathered clinical data. EP (0000-0001-9208-2987)* and DP (0000-0001-9588-7721)* evaluated the data from the statistical analysis. VT (0000-0003-4881-4241)* performed the literature search and review of the manuscript, and contributed to the intellectual concept of the study. ${ }^{\star} \mathrm{ORCID}$ (Open Researcher and Contributor ID).

\section{REFERENCES}

1. Braddom RL. Perils and pointers in the evaluation and management of back pain. Semin Neurol. 1998;18(2):197-210

2. Hall H. Back Pain. In: Noseworthy JH, editor-in-chief. Neurological Therapeutics Principles and Practice. $2^{\text {nd }}$ ed. Vol. I. Chapter 21. Oxon: Informa Healthcare; 2006. p. 240-56.

3. Jayson MIV. General aspects of back pain: an overview. In: Jayson MTV, Swezey RL, Knoplich J, et al., editors. Back pain, Painful Syndromes and Muscle Spasms: Current Concepts and Recent Advances. London: Partheon Publishing Group; 1990. p. $11-5$
4. Gerwin R, Dommerholt J, Shah J. An expansion of Simons' integrated hypothesis of trigger point formation. Curr Pain Headache Rep. 2004;8(6):468-75.

5. Yeung AT, Tsou PM. Posterolateral endoscopic excision for lumbar disc herniation: Surgical technique, outcome, and complications in 307 consecutive cases. Spine (Phila Pa 1976). 2002;1 (27):722-31.

6. Hoogland T, van den Brekel-Dijkstra K, Schubert M, Miklitz B. Endoscopic transforaminal discectomy for recurrent lumbar disc herniation: a prospective, cohort evaluation of 262 consecutive cases. Spine (Phila Pa 1976). 2008;33(9):973-8. 